\title{
SCIENCE
}

FRIDAY, NOVEMBER I8, I887.

The ClOSING SESsion of the National Academy of Sciences, which was held Friday at Columbia College, was perhaps the most interesting of the series that occupied the greater part of last week. Unfortunately, in view of this fact, the attendance was smaller than on any of the previous days, as several of the members had accepted an invitation from Professor Edison to visit Menlo Park. The session opened with an interesting paper by Prof. W. P. Trowbridge. It has always been a puzzle how the muscular action necessary to keep birds on the wing so long as they often remain could be possible; and Professor Trowbridge explained the recent discovery by his son, which is that birds of prey and some others have the power to lock securely together those parts of the wing holding the extended feathers and corresponding to the fingers of the human hand. The action of the air on the wing in this condition extends the elbow, which is prevented from opening too far by a cartilage, and the wings may keep this position for an indefinite length of time, with no muscular action whatever on the part of the bird. While resting in this way, the bird cannot rise in a still atmosphere; but, if there be a horizontal current, it may allow itself to be carried along by it, with a slight tendency downward, and so gain a momentum by which, with a slight change of direction, it may rise to some extent, still without muscular action of the wings. The professor also believed it quite possible for a bird to sleep on the wing. In discussing this paper, Prof. J. S. Newberry said that he had once shot a bird which came slowly to the ground as if still flying, but reached it dead. He believed that it had died high in the air; but he had never been able to account for the manner of its descent till now, when he found an explanation in the statement of Professor Trowbridge. Professor Newberry read a paper on the future of gold and silver production. Beginning with gold, he said that he had spent a part of nearly every summer since 1855 among the mines of the West, and he believed that the production of the United States was past its maximum. The present annual production amounts to $\$ 30,000,000$. In the northern parts of the mountains of the West there is probably gold, and it may be hoped that a considerable contribution to the gold of the world will be made from this region. There are no important deposits of gold in Mexico. The western coast of South America, rich in silver, is poor in gold. It is likely that the ancient inhabitants practically exhausted the supply, and the images of this metal which they buried with the dead have been sought, with some success. The product of Europe is about $\$ 30,000,000$ annually, more than three-fourths of which is from the Ural Mountains. We need not expect any such quantities of gold as flooded the world from California, Australia, and New Zealand, but it may be hoped that the present production may be kept up for many years. The problems of silverproduction for the future seem to lie wholly within our own country. There has been a production amounting to more than six thousand millions of dollars since the discovery of America, and it is likely to reach from forty to fifty millions annually for some years to come. The mines of Peru and Bolivia are the most famous in the world, and it is estimated that they have yielded $\$ 2,493,268$, 800 . Their yield has been comparatively little for many years. On Wednesday evening Mrs. Henry Draper gave a reception at her home, No. 27I Madison Avenue, to the members of the academy. The leading feature was an account given by Prof. E. C. Pickering, director of the Harvard Observatory, of the work in stellar photog- raphy under the provisions of the Henry Draper Memorial Fund. A full list of the papers read is given in another column.

At The anNUAL Fall MeEting of the trustees of Princeton, held Nov. Io, Dr. McCosh resigned the office of president, his resignation to take effect at the end of next term. In closing his annual report, Dr. McCosh said, "For several years past I have been sensitive as to whether I may not be continuing in my office to the detriment of the college. I am so far relieved by finding that no such effect has yet followed. Our entrance class this year, I79, is larger than ever it was before; as also our total number of students, 603. It was 264 when I came here, and this while we have gradually been raising our standard of scholarship. Thanks to our generous benefactors, our grounds and buildings, books . and apparatus, have been doubled or trebled. But having been in your service for over nineteen years, and being several years above the threescore and ten, the time has come to look to my retiring from the presidency of the college. I see it clearly to be my duty to ask the board to accept my resignation at its next meeting in February, and appoint a successor to me, it being understood that I retain my office till the beginning of the third term. I leave the college in a healthy state, intellectually, morally, and religiously." Dr. McCosh was born in Ayrshire, Scotland, in r8rr. Educated in the universities of Glasgow and Edinburgh, he early began to show signs of literary and philosophical talent of a high order. His first serious work, an essay on the Stoic philosophy, obtained for him the honorary degree of M.A., and he was ordained a minister of the Church of Scotland at Arbroath in 1835. In 1839 he removed to Brechin, and from that time he took a prominent part in the disputes which arose in connection with the disruption of the Scotch Church, and the organization of the 'Free Church,' which was effected in I 843. His next work to attract attention was "The Method of the Divine Government, Physical and Moral,' which was a theological application of Sir William Hamilton's philosophy. In 185 I he was appointed professor of logic and metaphysics in Queen's College, Belfast, and wrote, in collaboration with Prof. G. Dickie, 'Typical Forms and Special Ends in Creation,' and 'Intuitions of the Mind,' which were followed by 'An Examination of Mill's Philosophy.' Dr. McCosh was elected president of the College of New Jersey at Princeton in $\mathrm{r} 868$, and has held that office up to the present time. Among the works he has written in the mean time may be mentioned, 'The Laws of Discursive Thought,' 'Treatise on Logic,' 'Christianity and Positivism,' the 'Scotch Philosophy, Biographical, Expository, and Critical, from Hutcheson to Hamilton,' and his famous ' Reply to Professor Tyndall's Belfast Address.'

\section{THE 'ACT OF GOD' AND THE RAILWAY-COMPANY.}

So far back that memory of man runneth not to the contrary imported into the very earliest English jurisprudence from the Roman Code - was the theory of Nemesis, of the Inevitable, the Unavoidable. When it reached our motherland and Christian times, and clamored for recognition in the Common Law, our reverent Norman-Saxon lawyers, to be sure, called it the 'Act of God.' But it was the Stoic 'Fate' of the Roman - his 'Nemesis,' his 'Adrastea' - just the same; and the earliest English digests declared that 'the Act of God or of the public enemy' discharged all legal responsibility. In our day the doctrine is oftener laughed at than applied. A Western counsel for a railway-company, who, in defending an action for damages for haystacks destroyed by fire communicated from the company's locomotive, claimed that his 